\title{
Undervisning i selvmordsforebyggelse på grunduddannelserne i Danmark
}

Ved Inge Jacobsen

\begin{abstract}
I Danmark er der som opfølgning på den nationale handlingsplan "Forslag til handlingsplan til forebyggelse af selumordsforsøg og selvmord" (1998) afviklet 15 forsøgsprojekter med undervisning i selvmordsforebyggelse på grunduddannelserne. Undervisningen er gennemført på uddannelserne til social- og sundhedshjalper, social- og sundhedsassistent, sygeplejerske, paedagog, laerer, socialrådgiver og sognemedhjoelper. Denne artikel beskriver rammen om det overordnede projekt og udpeger nogle af problemfelterne. Herudover gives enkelte eksempler på de meget forskellige tilgange til undervisningen, som uddannelserne har valgt.
\end{abstract}

\section{Baggrund}

M ed iværksættelsen af den danske handlingsplan blev det bl.a. anbefalet at udarbejde moduler for en obligatorisk undervisning på grunduddannelserne (Sundhedsstyrel sen, 1998). D ette især med henblik på en systematisk opkvalificering af alle relevante faggrupper. Som led i en 3-åriguddannelsesplan ved C enter for Selvmordsforskning (Zø|lner, 2001) støttede Socialministeriet efter indstilling fra Referencegruppen til forebyggelse af selvmordsforsøg og sel vmord, udvikling og afprøvning af undervisning i selvmordsforebyggelse for en række særligt prioriterede uddannelser. D et kortsigtede mål var at udvikle, afprøve og beskrive undervisning i selvmordsforebyggel se; det langsigtede mål var og er en varig implementering af undervisningen på grunduddannelserne.

\section{Forberedelse af undervisningen}

For at klæde underviserne bedst muligt på - og for at lette processen med igangsættelse af forsøgsundervisning - inviterede $C$ enter for Selvmordsforskning uddannelsesansvarlige fra forskellige uddannelser til at deltage i et gratis seminar. I løbet af to dage blev præsenteret viden om selvmordsadfærd - herunder definitioner, teorier og forklaringsmodeller, myter, holdninger og etik, risikofaktorer og risikogrupper, behandlingsformer, m.m. $\mathrm{Og}$ deltagerne blev bedt om, i grupper, at udarbejde forslag til bl.a. omfang, placering og indhold af en given undervisning. På den måde fik deltagerne et arbejdspapir, de kunne bruge som udgangspunkt for en ansøgning om projektmidler.

\section{Prioriteringer}

Efter seminaret fik uddannel sesinstitutionerne (både de deltagende og ikkedeltagende) mulighed for at søge om midler til at udvikle og afprøve undervis- ning i selvmordsforebyggelse. Center for Selvmordsforskning vægtede især projekter, som indeholdt en tværfaglig undervisning, der også gik på tværs af emner, således at sel vmordsforebyggelse ikke kom til at stå som et isoleret tema. Derudover havde følgen de elementer højeste prioritet: holdningsdiskussioner (f.eks. etik, tabuer, myter) og kommunikationstræning (f.eks. "den vanskelige samtale"). $M$ ange af projekterne har inddraget minimum 2 fag og følgelig benyttet to undervisere (f.eks. inden for hhv. pædagogik og psykologi) og flere har ladet selvmordsforebyggelse indgå som emne i et forløb, hvor "forebyggel se" eller "sundhedsfremme" har været overskriften. For at projekterne ikke skulle blive for dyre - og sandsynligheden for gentagel se minimal blev den øvre grænse sat til DKK 40.000,pr. projekt. Der var afsat i alt DKK 800.000 ,- til støtte af projekter i perioden 2002-2004. C entret modtog 16 ansøgninger, hvoraf én blev afvist p. g. a. mangelfuld projektbeskrivelse. Det er vores erfaring, at det ikke er tilstrækkeligt fra centralt hold at udbyde en pulje til særligt prioriterede uddannelser, hvis udbyderne af de pågældende uddannelser ikke selv er rede til at prioritere et område højt. Der må gøres et grundigt forarbejde for at gøre institutionerne parate til at deltage i et forsøgsprojekt. A f de deltagende uddannelser viste pædagog- og social- og sundhedsuddannel serne størst interesse for at udvikle og afprøve moduler med undervisning i selvmordsforebyggel se.

\section{Afrapporteringer samlet $i$ et idékatalog}

M ed projektansøgningen forpligtede uddannel sesinstitutionerne sig til at indsende en afrapportering over forsøgsprojektet indeholdende en beskrivelse af: til rettel æggel se og gennemførelse af undervisningen, undervisningsmateriale/ litteraturliste, erfaringsopsamling med forslag til justeringer og en plan for implementering af undervisningen i egen institution. A frapporteringerne er siden redigeret og samlet i et katalog - med tilhørende fortegnelse over litteratur, relevante hjemmesider, film, gæstelærere, lovparagraffer, henvendel sessteder og an befal inger ved tilrettelæggel se af undervisning i selvmordsforebyggel se. I dékataloget, der udkom i maj 2004, har undervisere på de nævnte grunduddan nel ser som primær målgruppe, men også undervisere af andre faggrupper kan have udbytte af bogen.

\section{Følgegruppe}

I relation til forsøgs- og udviklingsarbejdet er nedsat en følgegruppe hvis kommissorium er: at følge og kommentere forsøgs- og udviklingsarbejdet med selvmordsforebyggende undervisning på grunduddannelserne, at vejlede og rådgive m. h. t. hvordan implementeringen mest hensigtsmæssigt gribes an, at støtte

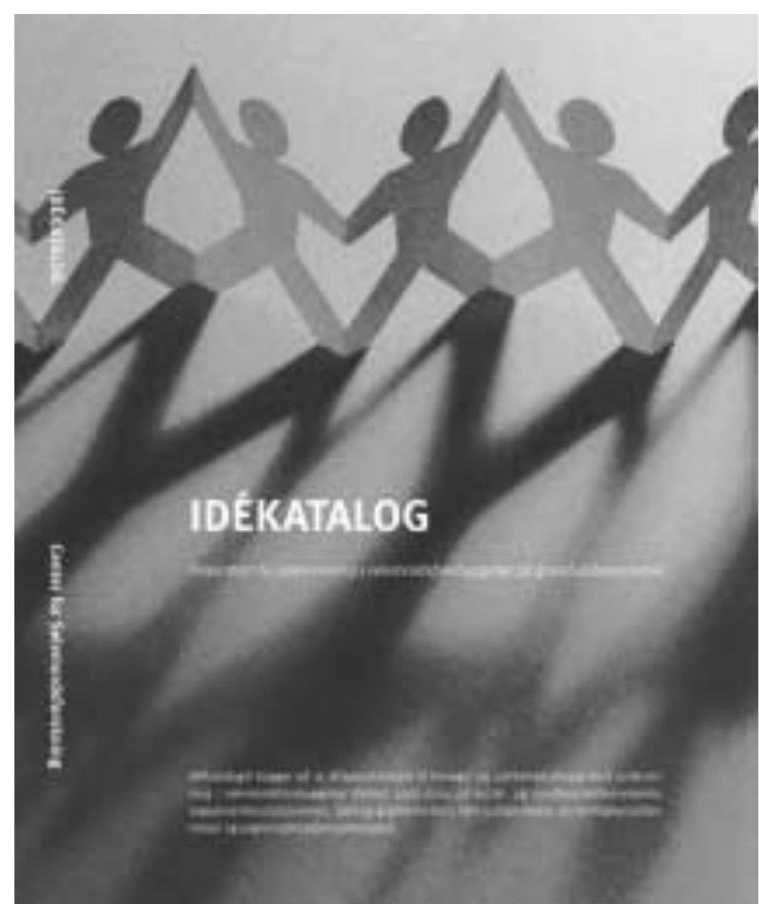


arbejdet med implementeringen i de respektive uddannel ser bl.a. ved at informere relevante instanser. Samarbejdet mellem centret og føl gegruppen har været udbytterigt og påvirket processen positivt.

\section{Eksempler på undervisningsmetoder}

De gennemførte projekter er af yderst forskellig karakter - både hvad længde, indhold og metode angår. N ogle uddannelser har koncentreret 6 timers undervisning i en temadag, andre har ladet emnet indgå i et semesterforløb (op til 45 lektioner) med en bredere overskrift, f.eks. "Børn og unge, hvor sundhed trues", "Fortællen de samvær". I det følgende bringes en kort omtale af udvalgte metoder.

\section{Film: D et tavse råb}

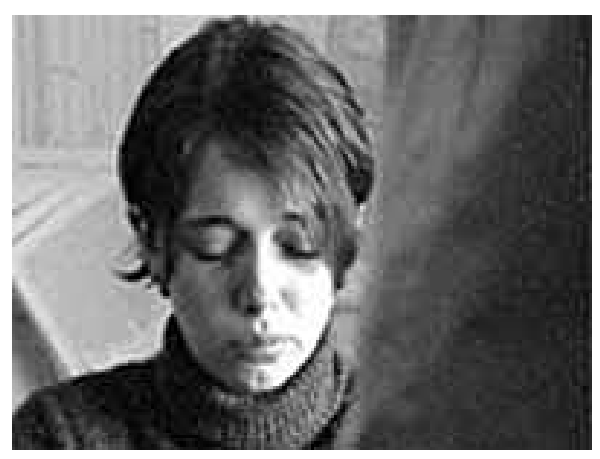

I størstedelen af projekterne er indgået en 19 minutter lang video, der er bygget op om en case med en lærer og en selvmordstruet studerende. Historien suppleres med information om intervention fra en skadestuesygeplejerske og en ungdomsrådgiver. Essensen af filmen er: "H ar du mistanke, så spørg". V ideoen har dels været anvendt som en indgang til emnet, dels dannet udgangspunkt for diskussioner om bl.a. etik, holdninger, myter og tabuer, og endelig har den været benyttet som oplæg til rollespil om den vanskelige samtale.

\section{Forumteater}

Et projekt - udført i et samarbejde mellem et pædagogseminarium og en social- og sundhedsskole - havde valgt at afprøve temadage med forumteater, en metode udviklet af brasilianeren A ugusto Boal. Forumteater er et skuespil, hvor et emne, en konflikt eller en problemstilling er samlingspunkt for tilskuerne, der kan påvirke handlingen direkte. Det er derfor egnet til komplekse problemstillinger. I déen er at tage udgangspunkt i deltagernes erfaringer, idéer og ressourcer og give dem plads til at opleve de følelser, der ligger bag. I forumteater skal problemstillingen være meget klart defineret fra start. Det skal være gennemskueligt, hvad og hvor det foregår, og hvem der er offer. M ed forumteater er det meningen, at publikum skal have mulighed for at ændre handlingen i stykket - ud fra læresætningen: "Jeg hører det, og jeg glemmer det. Jeg ser det, og jeg husker det. Jeg gør det, og jeg forstår det". De studerende udtrykte i deres evaluering af undervisningen stor begejstring for såvel metoden som det tværfaglige samarbejde.

\section{Fortællekreds - den narrative metode}

Et pædagogseminarium havde planlagt et semesterforløb med fokus på den narrative metode. På baggrund heraf arbejdede de studerende med fortællende samvær som lærings- og erkendelsesmåde. Der blev lagt vægt på betydningen af aktiv Iytning, empatisk forståelse og refleksion. Filosofien bag projektet var bl.a., at fortællende samvær kan give pædagogen indsigt i, hvordan det menneske han/hun er omsorgsperson for, tænker og føler. $\mathrm{Og}$ at det under samværet er tilladeligt at fortælle pædagogen om svære spørgsmål og kriser. Herudover kan det at dele sine tanker og følelser med andre i sig selv virke afklaren de og kan åbne for håb og nye muligheder. U nder forsøgsprojektet skulle de studerende først lære, hvordan en fortællekreds gennemføres - siden skulle de selv stå for gen nemførelse af fortællerunder med børn eller unge. Der var helt fastlagte regler for afvikling af fortællerunderne, der kunne tage udgangspunkt i 1. eller 3. persons fortællinger. $M$ ed 3. persons fortæll inger var det muligt at lægge en distance til det, man fortalte - eller at spejle sig i det. Der blev bl.a. fortalt på basis af udsagn som: Fortæl om et menneske, som har betydet meget for dig; Fortæl om en person, der var meget alene eller ensom. De studerende erfarede gennem deres projekter, at de børn og unge, som havde deltaget i fortællekredsen, blev så begejstrede for det, at de ønskede at fortsætte ud over projektperioden.

\section{Samtaletræning - huskeregler}

På en sygeplejerskeuddannelse blev der bl.a. arbejdet med at styrke de kommunikative redskaber. For at lære at spørge tæt ind til tanker og overvejelser om selvmord - og for at kunne handle hensigtsmæssigt herpå - udarbejdede studerende og undervisere i fællesskab et sæt huskeregler for samtal ens indhold og fokuspunkter. Til sammen udgjorde forbogstaverne ordet 'ansvar'.

\section{A - A Itid alvorligt}

En person, der udtrykker selv vage selvmordstanker, skal altid tages alvorligt. Du er forpligtet på at tage dig af ham eller hende. Det, der siges eller vises, kan/må ikke slås hen eller opfattes som tomme trusler eller afpresning.

\section{$\mathbf{N}$ - N ye løsninger}

D en selvmordstruede skal hjælpes til at se nye løsningsmuligheder. I sær fokuseres på livsbevaren de løsninger.

\section{S - Samtale}

Brug enkle spørgeteknikker i samtalen."H vordan har du det egentlig?". A bne spørgsmål og aktiv lytning.

\section{V - Videre til andre}

V ær klar over, hvem der tager sig af hvad. Sørg om nødvendigt for at følge den selvmordstruede eller sørg for at andre gør det. V ær sikker på, at andre overtager dit ansvar.

\section{A - A fhjæl pe belastninger}

$\mathrm{H}$ jæl $p$ den selvmordstruede til at finde muligheder for forandringer i sin livssituation eller opfattelse. Det kan ske ved, at du samtaler med vedkommende eller hjælper med praktiske foranstal tninger.

\section{R - R efleksion}

Forsøg at hjælpe den selvmordstruede til refleksion. $\mathrm{R}$ eflektér selv i og efter situationen, inddrag andre i dine tanker og overvejelser. Brug dine kolleger eller krisehjælp.

H uskereglen blev herefter trænet gennem rollespil i den vanskelige samtale. 


\section{Landsdaekkende seminar}

M ed henblik på at udbrede kendskabet til forsøgsundervisningen afholdt $\mathrm{C}$ enter for Selvmordsforskning i maj 2004 et erfaringsudvekslingsseminar på landsplan. U ndervisere fra alle i indledningen nævnte uddannelser blev inviteret. Ved seminaret fik deltagerne udleveret et eksemplar af idékataloget og diverse materialer, mulighed for at se filmen "Det tavse råb" og del tage i to workshoprunder med præsentationer af forsøgsprojekterne og endelig blev forumteatermetoden benyttet til i plenum - at sætte fokus på barrierer og dilemmaer i forhold til at undervise i selvmordsforebyggel se. En vigtig erfaring forsøgsprojekterne har gjort sig er netop, at det kan være ekstra vanskeligt at undervise i selvmordsforebyggelse, fordi enkelte studerende bliver så føl elsesmæssigt berørte af det, at de må forlade undervisningen. Som underviser er det vigtigt at være forberedt på, hvordan man bedst håndterer dette. $\mathrm{H}$ vis det ikke er muligt at være to undervisere, kan man f.eks. aftale med de studerende, at de holder øje med hinanden parvis.

\section{De helt centrale personer er underviserne}

Fokus for dette projekt har især været igangsættelse af undervisning i selvmordsforebyggelse. I forhold hertil er underviserne de helt centrale personer. U den deres interesse og engagement for emnet - ingen undervisning i selvmordsforebyggelse. Fra de første seminarer for uddannelsesan svarlige stod det klart, at underviserne mangl ede viden om selvmordsadfærd, at de havde brug for at diskutere holdninger og etik, og at de fandt stor støtte i - via projektmidlerne - at få mulighed for at afprøve derestanker i praksis. For at servicere underviserne bedst muligt, har C enter for Sel vmordsforskning Iøbende orienteret dem om ny litteratur, relevante hjemmesider, konferencer, m.m. D enne service planlægges integreret i centrets nye hjemmeside, således at alle undervisere får mulighed for at tilmelde sig automatisk udsendel se af nyheder.

\section{Implementering af undervisningen?}

Det overordnede projekt har mødt en del udfordringer undervejs: nye bekendtgørelser (hvilket medførte, at mange ud- dannelser underviste efter både en ny og en gammel studieordning på samme tid), sammenlægning af uddannel sesinstitutioner i C VU (C entre for V ideregående U ddannelse) og en kort horisont for ansøgning om samt udvikling og afprøvning af forsøgsundervisningen (1 skoleår). A f de deltagende uddannelsesinstitutioner har hovedparten implementeret hele eller dele af den afprøvede undervisning. M en ting tager tid. U ndervisning i selvmordsforebyggelse implementeres ikke over én nat - eller i løbet af 3 år for den sags skyld. $0 \mathrm{~g}$ det sker heller ikke på baggrund af 15 gennemførte projekter. En implementering kræver opfølgning og gerne en afdækning af, hvordan, hvor, i hvilket omfang og for hvem der tilbydes undervisning. C enter for Selvmordsforskning vil fortsætte arbejdet på to planer: lokalt og centralt. Derfor gennemfører centeret netop nu ovennævnte afdækning, dels for at støtte de uddannel sesinstitutioner, der allerede har implementeret undervisning i selvmordsforebyggelse, dels for at motivere de øvrige institutioner til at gå i gang. H erudover vil centret arbejde for en implementering, ved at det fra centralt hold anbefales at lade undervisning i selvmordsforebyggelse indgå som en obligatorisk del af alle relevante uddannelser.

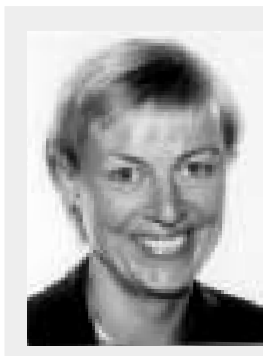

Inge Jacobsen har siden 2001 arbej det som uddannelseskonsulent ved C enter for Selvmordsforskning i 0 dense, Danmark. U d over det beskrevne projekt har hun bl.a. haft ansvar for udvikling og implementering af efteruddannel-

seskurser for lærere og psykologer, oprettel se af netværk for og database over undervisere, udarbejdelse af undervisningsmateriale og afholdelse af temadage for un dervisere.

Center for Selvmordsforskning varetager forskning i selvmordsadfærd, registre for selvmord og selvmordsforsøg, viden sformidling og uddannelse. Centret, der har eksisteret siden 1989, er en selvejende institution under Social ministeriet.

\section{Referencer}

Jacobsen, I. (red.). (2004). I dékatalog - inspiration til undervisning i selvmordsforebyggelse på grunduddannelserne. Center for selvmordsforskning.

Forslag til handlingsplan til forebyggelse af selvmordsforsøg og selvmord i D anmark. U dval get til udarbejdelse af forslag til handlingsplan til forebyggelse af sel vmordsforsøg og selvmord i Danmark - København: Sundhedsstyrelsen, 1998. (kap. 9. G rund-, videre- og efteruddannelse, s. 71-77)

Zøllner, L. (2001). U ddannelsesplan. Center for Selvmordsforskning

\section{Yderligere information og litteraturtips}

Interesserede læsere kan downloade idékataloget (Jacobsen (red.), 2004) fra centrets hjemmeside www.selvmordsforskning.dk

eller rekvirere det på tel efon + 4566138811 eller e-mail info@selvmordsforskning.dk mod betaling af forsendel se og gebyr.

\section{D et tavse råb}

Filmen kan bestilles gennem Det Danske Filminstitut.

http://www.dfi.dk/sitemod/moduler/katalog/ filmside. asp?pid=8670\& fil mid $=14000$

U ndervisningsmaterialet til filmen er beskrevet i artikel i $N$ yhedsbrev om selvmordsforebyggelse, nr. 2, 2003 (s. 8).

http://www.selvmordsforskning.dk/filecache/9083 /1100511935/nyhedsbrevnr.22003.pdf

Selve materialet kan downloades fra Sundhedsstyrelsens hjemmeside:

http://www.sst.dk/Forebyggelse/Faglige_omraader/ Selvmordsforebyggelse/U n dervisningsmateriale. aspx? lang=da

\section{Metodebøger til forumteater}

Boal, A . (1995). Spil. Teaterforlaget

Boal, A . (1985). Stop - det er magisk.

Teaterforlaget

\section{M etodebøger til fortællekreds}

C hristensen, P. H., H ansen, E. \& Vejleskov, H. (1997). D et narrative - fra metapsykologi til puslebord. Skrifter fra C enter for Småbørnsforskning, nr. 9, Kroghs Forlag

H orsdal, M . (1999). Livets fortællinger - en bog om livshistorier og identitet. Borgens forlag.

Lundby, G . (2000). N arrativ Terapi. Socialpædagogisk Bibliotek, Gyldendal.

Sejlelid, E. P. (2002). Kan omsorg læres? - Fortellingen som pedagogisk hjelpemiddel.

Fagbokforlaget, Bergen 